\title{
Title:
}

\section{Gruber-Frantz tumor: a rare pancreatic neoplasm}

\section{Authors:}

Joel Omar Jáquez-Quintana, Héctor Jesús Maldonado-Garza, Carolina Ivette Zubía-Nevárez

DOI: $10.17235 /$ reed.2021.8345/2021

Link: PubMed (Epub ahead of print)

Please cite this article as:

Jáquez-Quintana Joel Omar, Maldonado-Garza Héctor Jesús, Zubía-Nevárez Carolina Ivette. Gruber-Frantz tumor: a rare pancreatic neoplasm. Rev Esp Enferm Dig 2021. doi: 10.17235/reed.2021.8345/2021.

This is a PDF file of an unedited manuscript that has been accepted for publication. As a service to our customers we are providing this early version of the manuscript. The manuscript will undergo copyediting, typesetting, and review of the resulting proof before it is published in its final form. Please note that during the production process errors may be discovered which could affect the content, and all legal disclaimers that apply to the journal pertain. 
Gruber-Frantz tumor: a rare pancreatic neoplasm

Joel Omar Jáquez-Quintana ${ }^{1}$, Héctor Jesús Maldonado-Garza ${ }^{1}$, Carolina Ivette Zubía-Nevárez ${ }^{2}$

${ }^{1}$ Departament of Gastroenterology and Digestive Endoscopy. University Hospital “Dr. José Eleuterio González", Nuevo Leon Autonomous University. Nuevo León, Mexico.

${ }^{2}$ Department of Internal Medicine. Christus Muguerza del Parque Hospital. University of Monterrey. Chihuahua, Mexico.

\section{Corresponding Author:}

Joel Omar Jáquez-Quintana. E-mail: jomjaqui@hotmail.com.

Keywords: Neoplasm. Pancreas. Tumor.

\section{Mr. Editor}

We present the case of a 37-year-old woman with abdominal pain in the epigastrium radiating to the right flank for a month of evolution. On physical examination, epigastric mass is palpated, firm and painless. Computed tomography (CT) showed a cystic tumor in the body and tail of the pancreas with solid areas and defined borders $(12 \times 10 \mathrm{~cm})$, which displaces structures (Fig. 1-A). Endoscopic ultrasound (EUS)-guided fine needle biopsy was taken, with consistent cytology of SPT. Subsequently, a distal pancreatectomy with tumor resection and nodal dissection was performed (Fig. 1-B). Cytology reported discohesive cells, some arranged around capillaries, with small nuclei with clefts (Fig. 1-C), CK7 negative and $\beta$-catenin positive (Fig. 1-D). After 4 years of follow-up, there is no evidence of recurrence.

\section{Discussion}


Pancreatic SPT is rare (1-2\% of pancreatic neoplasms), of low-degree malignancy (10-15\%) and generally, in young women (25-35 years-old). It is diagnosed in asymptomatic patients as incidental finding or by nonspecific abdominal pain with/without mass effect. It is typically a large solitary lesion (6-22 centimeters) on the body and tail of the pancreas (1).

Diagnosis is by TC/MRI. In portal-venous CT, an encapsulated tumor of a solid-cystic component with intramural hemorrhage without communication to the pancreatic duct is observed. EUS is useful to characterize the lesion and taking biopsies (2). Histologically, it has monomorphic discohesive cells separated from capillaries with oval or cercariform nuclei in hyalinized myxoid material and PAS-positive grouped globules. The main positive markers are $\beta$-catenin, cyclin D-1, CTNNB1 and vimentin (3).

Treatment is surgical if the tumor is localized and circumscribed. Recurrence and 5-year survival are $<10 \%$ and $>96 \%$, respectively (1-2). Metastases are usually hepatic and chemotherapy, arterial embolization (4) and radioablation (5) are described as treatment options. Its accurate diagnosis considerably improves the prognosis with respect to others pancreatic neoplasms.

\section{References:}

1. Zalatnai A, Kis-Orha V. Solid-pseudopapillary Neoplasm of Pancreas is still an enigma: a Clinicopathological Review. Pathol Oncol Res. 2020; 26(2): 641-9. Epub 2019 Jun 17. DOI: 10.1007/s12253-019-00671-8.

2. Gandhi D, Sharma P, Parashar K, et al. Solid pseudopapillary Tumor of the Pancreas: Radiological and surgical review. Clin Imaging. 2020; 67:101-7 Epub 2020 Jun 9. DOI: 10.1016/j.clinimag.2020.06.008.

3. La Rosa S, Bongiovanni M. Pancreatic Solid Pseudopapillary Neoplasm: Key Pathologic and Genetic Features. Arch Pathol Lab Med. 2017 Jul;141(7):990-995. DOI: 10.5858/arpa.2016-0322-RS.

4. Milanetto, AC, Gais Zürcher, AL, Macchi, L, et al. Pancreatic solid pseudopapillary neoplasm in male patients: systematic review with three new cases. Updates in Surgery. (2020). DOI: 10.1007/s13304-020-00905-4. 
5. Lin X, Lin R, Lu F, et al. Surgical Management of Solid Pseudopapillary Neoplasms of Pancreas: A Single-Center Experience of 60 Patients. Dig Surg. 2020;37(4):348-354. Epub 2020 Jan 20. DOI: 10.1159/000505062.
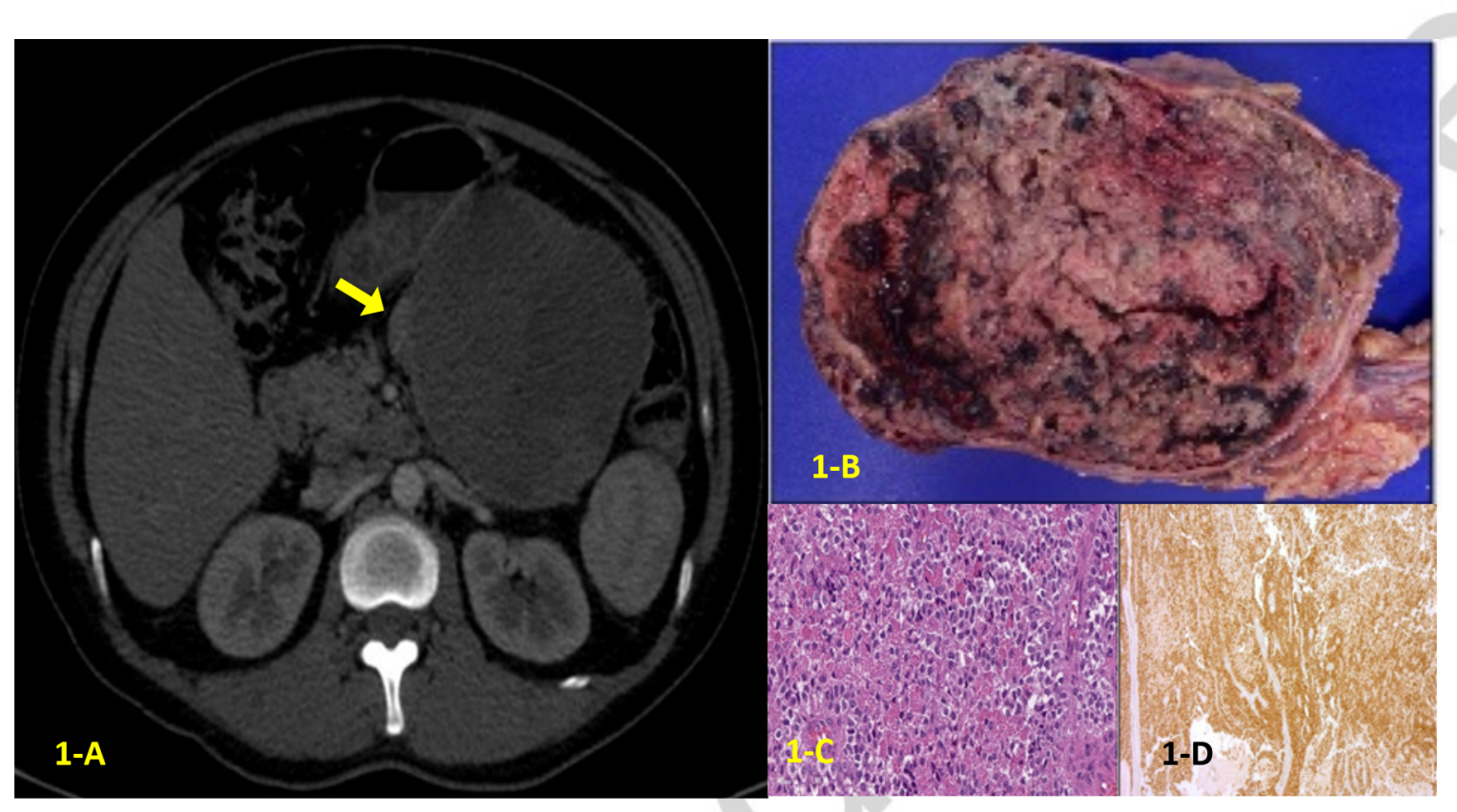

Fig. 1-A) Axial abdominal tomography image in arterial phase demonstrates a cyst tumor in the body and tail of the pancreas with solid component (yellow arrow) that displaces intestinal loops, without adenopathies. 1-B) Surgical specimen with integral capsule. 1-C) Histopathology with cells arranged along vascular septa with small nuclei, mild anisonucleosis and nuclear clefts. 1-D) Immunohistochemistry for $\beta$-catenin expression was positive in the nuclei. 